\title{
Phytoplankton and bacteria over the transient area of the continental slope of the Celtic Sea in spring. I. Vertical distribution and productivity
}

\author{
V. Martin-Jézéquel ${ }^{1}, C$. Videau ${ }^{2}$ \\ ' Observatoire Océanologique de Roscoff, UPR 4601, CNRS \& Université Paris VI, Station biologique, BP 74, \\ F-29682 Roscofi Cédex, France \\ ${ }^{2}$ Laboratoire de Physiologie Végétale, Université de Bretagne Occidentale, F-29287 Brest Cédex, France
}

\begin{abstract}
The environmental and ecological determinants of larval survival and recruitment of Scomber scombrus were investigated in May 1987, during an interdisciplinary cruise on the continental slope at the edge of the Celtic Sea. The present paper relates some of these results to the microbial characteristics. Three locations were chosen along a narrow horizontal scale between the stratified waters of the continental shelf and the mixed waters of the shelf-break. In the subsurface layers, primary productivity as well as chlorophyll biomass increased proportionally to the stratification. Conversely, bacteria cell numbers progressively increased from the stratified water column to the mixed one. Bacterial net production was twice as high in mixed as in stratified waters. A correspondence analysis showed differences in the composition and production of phytoplankton and bacteria at the 3 locations. This analysis characterized mixed waters by bacterial biomass, bacterial carbon production, and ciliate biomass, transitional waters by diatom and dinoflagellate biomass, and stratified waters by Cryptophyceae, flagellates and total phytoplankton biomass. Chlorophyll appeared independent of the 3 locations, suggesting that chlorophyll alone is not sufficient to study this particularly variable and complex environment. Bacterial specific growth rate and phytoplankton carbon production were also independent of the 3 locations. The classical food web structure was found relative to the degree of stratification of the water masses. But, compared to previous knowledge of the microbial distribution, an unusual importance of bacterial and ciliate components in the mixed waters was observed, related to other characteristics of the food chain at this station, such as larval mortality. It is suggested that the spring tidal regime and an early establishment of the food chain were responsible for these results.
\end{abstract}

\section{INTRODUCTION}

The Western stock of mackerel Scomber scombrus overwinters in various regions from the west coast of Scotland to the northwest coast of France. The Celtic Sea shelf edge in the vicinity of the Great Sole and Cockburn Banks is important for fisheries (Coombs et al. 1983). This area is characterized by a frontal transition NW/SE of the water masses, occurring between eastern stratified waters and western mixed waters. Canyons and ridges give an irregular bottom topography. The influence of the shelf topography on tidal effect causes vertical mixing in the region, and the suitability for mackerel spawning results from the enhanced productivity of this area. Spawning occurs in early spring, and later in the season mackerel egg production peaks concomitantly with the thermocline development in the Celtic Sea shelf waters.

A cruise was undertaken in May 1987 on the continental slope at the edge of the Celtic Sea shelf to investigate the environmental and ecological determinants of larval survival and recruitment on horizontal and vertical scales. The hydrographic survey showed the occurrence of stratified conditions over the ridges, while vertically mixed conditions were found extending onto the shelf within the troughs. The specific aim of the present study was to investigate the biomass, production and specific composition of the phytoplankton in this area and the accompanying changes in the biomass and activity of the bacteria. 
The critical period concept maintains that herring larval survival and hence recruitment are primarily determined by food limitation in the early larval stage. The 'match-mismatch' hypothesis of Cushing (1975) or the 'stable ocean hypothesis' of Lasker $(1975,1981)$ explain the success or failure of a year class through its dependence on the plankton development. The concept of the 'larva retention area' (Iles \& Sinclair 1982, 1985) implies that larvae, upon hatching, are retained in a specific area characterized by certain oceanographic properties. These concepts represent match by retention in time or retention in distance. Depending on species, both can operate to some extent independently. Variation in larval food availibility may potentially contribute to recruitment variability, while competition for food may lead to density-dependent regulation of recruitment (Kiørboe et al. 1988). Thus the association of herring spawning grounds with hydrographic discontinuities is striking, and the interaction between larval biology and hydrographic features may be a determining factor in larval survival and hence recruitment (Kiørboe et al. 1988).

Over the shelf, phytoplankton populations are influenced by changes in advective movements in the water column (Pingree \& Mardell 1981, Pingree et al. 1982a). Variation in phytoplankton species composition may recur on a small horizontal scale, in association with vertical mixing events (cf. Kiørboe et al. 1990). Most of the previous studies considered only biomass and production rate of the phytoplankton. In this study, we focused on the specific composition of the phytoplankton population, which gave new information on the pelagic food web structure in relation to hydrodynamic processes. Also, the specific distribution of phytoplankton, as well as its size, may influence the structure of the pelagic food chain by inducing the composition of the grazers and the ultimate path toward another trophic level. Algal production is exported either through the herbivore pathway toward higher trophic levels such as zooplankton and ultimately fish, or through the decomposer pathway toward microheterotrophs with bacteria as the first link. Since the switching between the 2 pathways is governed by the degree of matching between the temporal characteristics of physical phenomena and those of biotic responses (Legendre \& Le Fèvre 1989), a stratified area on the Cockburn Bank as well as a mixed and a transitional area at the shelf edge were studied to define the environmental conditions found at the time of larvae development.

\section{MATERIAL AND METHODS}

The survey was conducted in the Celtic Sea during the cruise 'ROSIMER 87' aboard the RV 'Thalassa' (IFREMER, France) between 30 April and 15 May 1987 in collaboration with British scientists (PML, Plymouth, UK). The studied area was first investigated on a large spatial scale by means of an Undulator Oceanographic Recorder (UOR) and CTD stations spaced at $10 \mathrm{n}$ mile intervals along several longitudinal transects across the Great Sole Bank and the Cockburn Bank. UOR data (temperature, chlorophyll, zooplankton and ichthyoplankton), vertical temperature and salinity measurements (Guildline CTD), chlorophyll profiles (in situ fluorometer Variosens), zooplankton and ichthyoplankton abundances (Bongo nets) allowed 2 points to be selected as representative of the stratified water masses (Point S) on the continental shelf and, on the other hand, of the mixed water masses (Point $M$ ) on the continental shelf-break (Fig. 1). Each point was studied (while remaining in the area for 3 to $4 \mathrm{~d}$ ) from a biological interdisciplinary point of view in order to define the environmental conditions related to the occurrence and abundance of mackerel fish eggs and larvae. Microbial characteristics only will be reported in this paper (the full data are presented in Poulet et al. 1988).

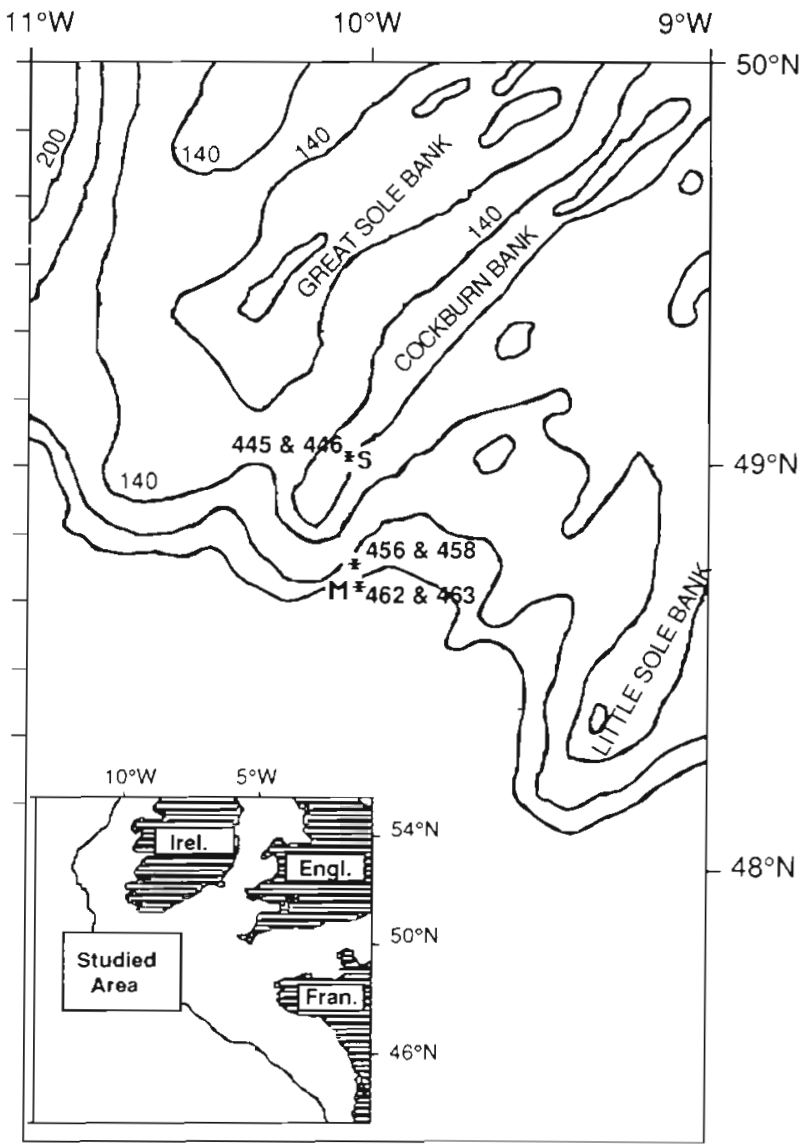

Fig. 1. Celtic Sea study area. $S$ was located in the stratified waters of the continental shelf and $M$ in the mixed waters on the continental shelf-break. Stns $445 \& 446$ : stratified waters; Stns 456 \& 458: transitional waters; Stns 462 \& 463: mixed waters 
Measurements made during long-term ( 3 to $4 \mathrm{~d}$ ) studies included bacterial production, primary productivity and chlorophyll biomass of size-fractionated phytoplankton, bacterial and phytoplankton specific growth rates and phytoplankton species composition. Locations of the 6 stations are shown in Fig. 1. Phytoplankton cell counts and chlorophyll data were obtained at Stns 445 . 456 and 463 , and all the other parameters (bacterial production, primary productivity and chlorophyll biomass of size-fractionated phytoplankton, bacterial and phytoplankton specific growth rates) at Stns 446, 458 and 462. Stns $445\left(49^{\circ} 0^{\prime} 24^{\prime \prime} N, 10^{\circ} 3^{\prime} 85^{\prime \prime} \mathrm{W}\right)$ and 446 ( $48^{\circ} 59^{\prime} 84^{\prime \prime}$ $\left.\mathrm{N}, 10^{\circ} 3^{\prime} 29^{\prime \prime} \mathrm{W}\right)$, representative of stratified waters, were sampled on 9 and 10 May, Stns $456\left(48^{\circ} 42^{\prime} 51^{\prime \prime} \mathrm{N}\right.$, $\left.10^{\circ} 6^{\prime} 33^{\prime \prime} \mathrm{W}\right)$ and $458\left(48^{\circ} 42^{\prime} 37^{\prime \prime} \mathrm{N}, 10^{\circ} 6^{\prime} 4^{\prime \prime} \mathrm{W}\right)$ were called transitional waters and sampled on 11 and 12 May, and Stns $463\left(48^{\circ} 42^{\prime} 30^{\prime \prime} \mathrm{N}, 10^{\circ} 6^{\prime} 24^{\prime \prime} \mathrm{W}\right)$ and $462\left(48^{\circ} 42^{\prime} 32^{\prime \prime} \mathrm{N}, 10^{\circ} 6^{\prime} 70^{\prime \prime} \mathrm{W}\right)$, representative of mixed waters, were sampled on 13 May. During this period, the tidal cycle progressed from a neap (6 May) to a spring situation (13 May)

Water samples were collected with Niskin bottles coupled to the sampling rosette of a Guildline 8705 CTD system in conjunction with a computer. Vertical structure profiles were determined as the CTD was lowered and water samples were collected at various selected depths as the unit was pulled back to the surface. Chlorophyll and phytoplankton cell counts were made at 11 depths in the upper $60 \mathrm{~m}$. Chlorophyll concentrations were determined fluorometrically (Turner model 111 fluorometer) after filtration (Whatmann GF/F) and extraction in $90 \%$ acetone (Lorenzen 1966) following Yentsch \& Menzel's (1963) procedure. Phytoplankton samples were preserved in Lugol's acid solution and cell counts were made on settled $50 \mathrm{ml}$ samples with an inverted microscope. Two cell sizes were counted in each sample, cells $\geq 5$ or $<5 \mu \mathrm{m}$. Optical observations did not allow us to distinguish cells $<1 \mu \mathrm{m}$. Consequently, the size fraction $<5 \mu \mathrm{m}$ corresponds to cells $<5 \mu \mathrm{m}$ and $\geq 1 \mu \mathrm{m}$. Specific determination allowed us to distinguish major Rhizosolenia sp., Nitzschia sp. and Thalassiossira sp. among the diatoms. Dinoflagellates $>5 \mu \mathrm{m}$ were recognized as well, without determination to species Dinoflagellates $<5 \mu \mathrm{m}$ were unrecognizable and included in the undetermined flagellates in this size class.

Surface irradiance was continuously recorded by a Licor quantum sensor (400 to $700 \mathrm{~nm}$ ) and light attenuation was estimated at each station from a Secchi disk. Four light levels $(50,25,10$ and $1 \%$ of surface light intensity) only were considered for carbon fixation and size fractionation to limit experimental time. Duplicate samples prefiltered onto a $200 \mu \mathrm{m}$ Nytrel mesh, from each light level, were incubated in $125 \mathrm{ml}$ glass bottles in the presence of $0.18 \mathrm{MBq} \mathrm{Na}{ }^{14} \mathrm{CO}_{3}$ (C.E.A., France). Samples were incubated on deck for $4 \mathrm{~h}$ under nickel screens simulating in situ light levels. Thermal regulation was ensured by a surface seawater flow $\left(\mathrm{T}=12^{\circ} \mathrm{C}\right)$ After incubation, samples were successively filtered onto 5, 1 and $0.2 \mu \mathrm{m}$ pore size Nuclepore membranes. Then they were rinsed with $100 \mathrm{ml}$ of filtered seawater, before being frozen at $-20^{\circ} \mathrm{C}$. Tests showed that inorganic carbon retention did not exceed $50 \mathrm{dpm}$, and this value was subtracted from all the measurements. After drying, radioactive carbon was assessed by liquid scintillation counting (Picofluor 30 liquid and Tricarb 300 Scintillation Counter, Packard). During incubation, 11 of water sample was fractionated as above for chlorophyll measurements.

Specific growth rates of phytoplankton assemblages from surface and light-limited depths were estimated by the ${ }^{14} \mathrm{C}$-chlorophyll labeling method (Redalje \& Laws 1981). Four liters of seawater sample were inoculated with $9.25 \mathrm{MBq} \mathrm{Na}{ }^{14} \mathrm{CO}_{3}$ solution (specific activity: 1.5 to $2.5 \mathrm{TBq} \mathrm{mmol}^{-1}$ ) and incubated in a polycarbonate bottle from dawn to dusk under nickel screens simulating the light level they came from. After incubation, samples were collected onto Whatmann GF/F filters and stored at $-20^{\circ} \mathrm{C}$ for subsequent analysis. To determine the specific activity of carbon contained in chlorophyll, the procedure of Welschmeyer \& Lorenzen (1984) was followed. Concentrated pigments were then separated 2-dimensionally onto cellulose plates (HPTLC for nano thin-layer chromatography, Merck); first dimension, $n$-propanol:light petroleum $\left(60\right.$ to $\left.80^{\circ} \mathrm{C}\right)=2.5: 97.5$ $(\mathrm{v} / \mathrm{v})$; and second dimension, light petroleum (60 to $\left.80^{\circ} \mathrm{C}\right)$ : chloroform : acetone $=70: 30: 0.5(\mathrm{v} / \mathrm{v} / \mathrm{v})$ (Jeffrey 1981). The chl a spot was identified under UV light, scraped off the plate, eluted with $3 \mathrm{ml} 90 \%$ acetone and allowed to extract at $-20^{\circ} \mathrm{C}$ for $1 \mathrm{~h}$. The extracted pigment was separated by centrifugation. A $1 \mathrm{ml}$ aliquot of the extract was then taken and diluted to $3 \mathrm{ml}$ for chlorophyll measurement on a fluorometer. The remaining $2 \mathrm{ml}$ of extract was allowed to evaporate before adding liquid scintillation cocktail to reduce quenching

The specific activity of chlorophyll, $R^{*}$, was determined from the equation:

$$
R^{\cdot}=\frac{\mathrm{dpm}(\mathrm{ml} \text { extract })^{-1}}{(\mu \mathrm{g} \mathrm{chl} \mathrm{a})(\mathrm{ml} \text { extract })^{-1} \times 0.7399}
$$

where $0.7399=$ carbon fraction of chl a molecule.

The specific growth rate, $\mu\left(\mathrm{d}^{-1}\right)$, of the phytoplankton was calculated as

$$
\mu=-\ln \left[1-\left(1.05 R^{*} \times I^{*-1}\right)\right] \times 1 / t
$$

where $I^{*}=$ specific activity of dissolved inorganic carbon (dpm $\mu \mathrm{g}^{-1}$ ); and $t=$ duration of incubation (d). $R^{*}$ was corrected by 1.05 , the isotopic discrimination factor. 
Bacterial production was determined by measuring tritiated thymidine incorporation (Furhman \& Azam 1982). $20 \mathrm{ml}$ duplicate water samples were incubated with $4.5 \mathrm{nM}{ }^{3} \mathrm{H}$-methyl thymidine (C.E.A., France) with a specific activity of $5.65 \times 10^{16} \mathrm{dpm} \mathrm{mmol}{ }^{-1}$ for $2 \mathrm{~h}$ at sea surface temperature $\left(12^{\circ} \mathrm{C}\right)$. At the end of the incubation, samples were poured into an ice-cold plastic tube. $20 \mathrm{ml}$ ice-cold $10 \%$ trichloroacetic acid (TCA) were added and soluble pools extracted for $5 \mathrm{~min}$. Samples were then filtered onto a $0.45 \mu \mathrm{m}$ pore size Millipore membrane, rinsed 5 times with $1 \mathrm{ml}$ ice-cold $5 \%$ TCA and frozen at $-20^{\circ} \mathrm{C}$ until ${ }^{3} \mathrm{H}$-thymidine incorporation was measured by liquid scintillation counting. Incorporated thymidine was then calculated from the ratio of radioactivity in the sample to the specific activity of the inoculated labeled thymidine. Bacterial production was estimated assuming that a mean value of $1.7 \times 10^{18}$ cells were produced per mole of thymidine incorporated (Furhman \& Azam 1982). This production could be expressed in $\mathrm{mg} C$ from a conversion factor of $1.7 \times$ $10^{-9} \mu \mathrm{g} \mathrm{C}$ cell $^{-1}$ (Watson et al. 1977), which corresponds to a carbon content of $0.12 \mathrm{pg} \mathrm{C} \mu \mathrm{m}^{-3}$ (biovolume). This value is twice as low as Kuparinen's (unpubl. data in Kuosa \& Kivi 1989), and 3 times lower than the value used by Bjørnsen et al. (1988). Although no statistic measurements were made, epifluorescence microscopic examination showed that bacteria cells in our samples were very small with a cell diameter of about $0.3 \mu \mathrm{m}=$ biovolume of $0.015 \mu^{3}$, which is lower than the traditionally observed value of $0.046 \mu^{3}$ (Fuhrman et al. 1980 , Kuosa \& Kivi 1989), or even than the value of $0.08 \mu^{3}$ used by Sherr \& Sherr (1987). For these reasons, we chose to use the lowest conversion factor. Bacteria cell numbers were estimated on fixed samples with $2 \%$ gluteraldehyde (final concentration) after being filtered onto a $0.2 \mu \mathrm{m}$ Nuclepore filter, by the acridine orange epifluorescence technique. Bacterial growth rates were estimated from the cell counts and the number of cells produced during the incubation time.

Results from the upper $25 \mathrm{~m}$ layer of each of the 3 water types were analyzed using factorial correspondence analysis (Benzecri 1970, Teil 1975). This analysis is a double principal component analysis which uses the $\mathrm{Chi}^{2}$ distance to compare the data. To build the matrix, the raw data for every depth and every station were rescaled, so that all ranges were similar: cell numbers of each phytoplanktonic species and size class, total and size-fractionated chlorophyll, total and size-fractionated phytoplanktonic carbon production, bacterial biomass, carbon production and growth rate. Projection of the 3 water types and the biological data on the first 2 axes of the resulting diagram accounts for $87 \%$ of the variability.
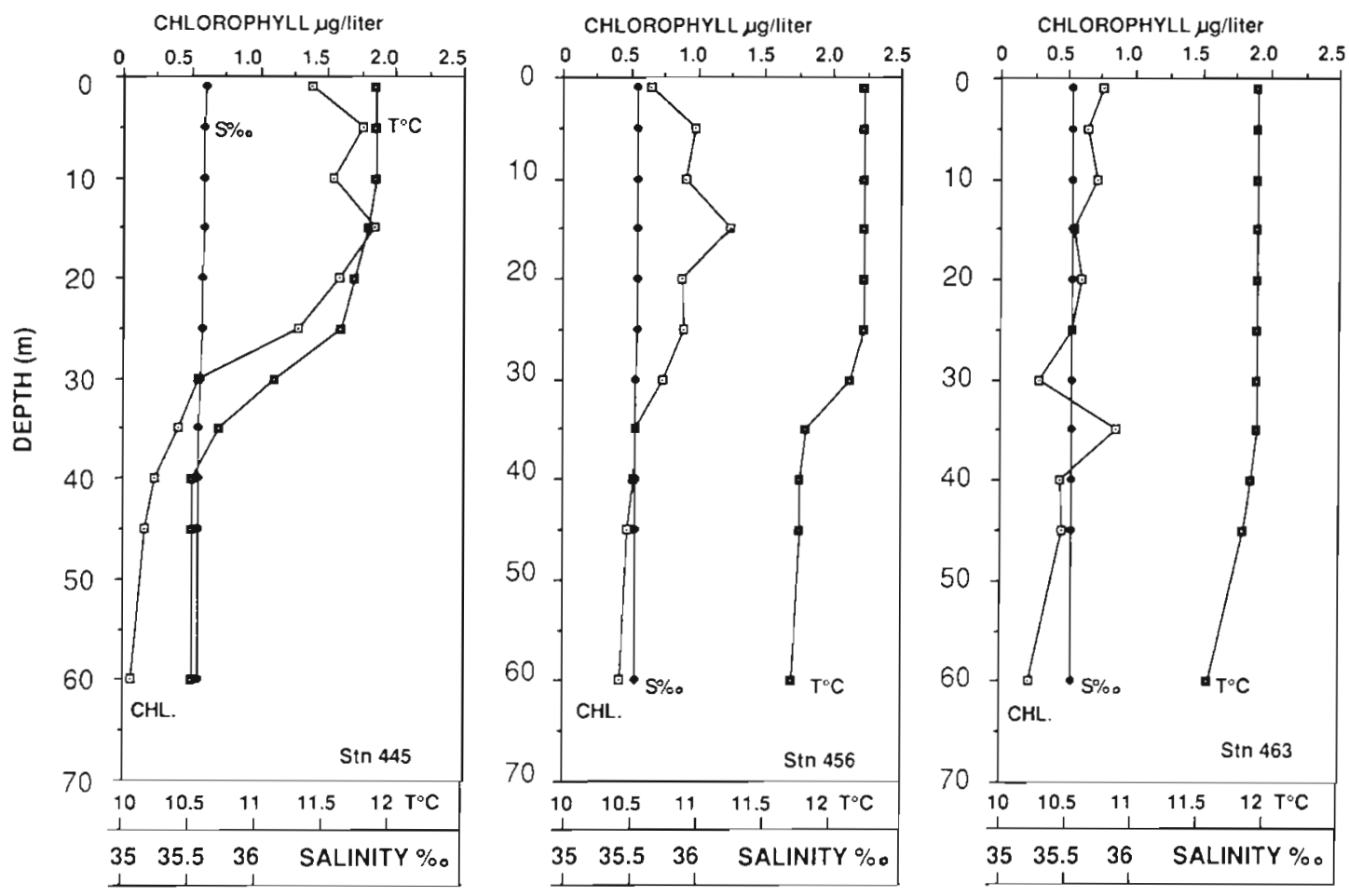

Fig. 2. Temperature, salinity and chlorophyll vertical profiles for stratified (Str 445), transitional (Stn 456) and mixed (Stn 463) stations 


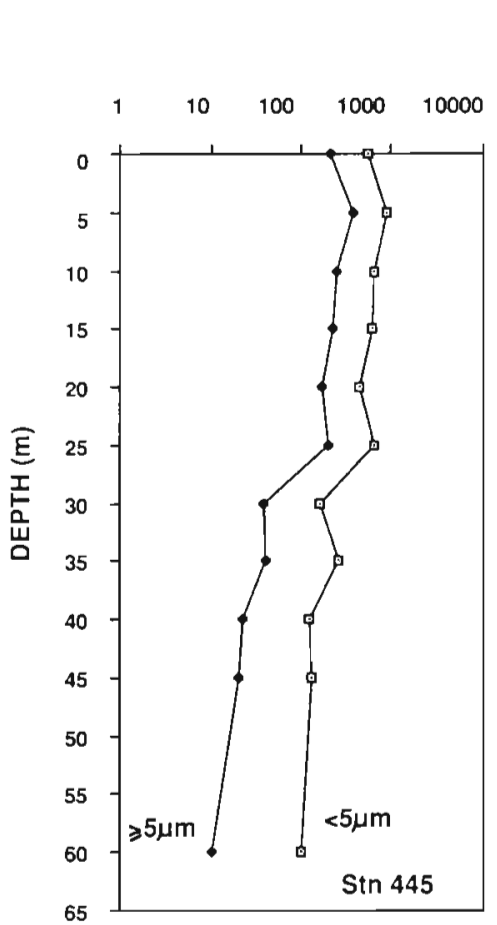

\section{CELL NUMBER}
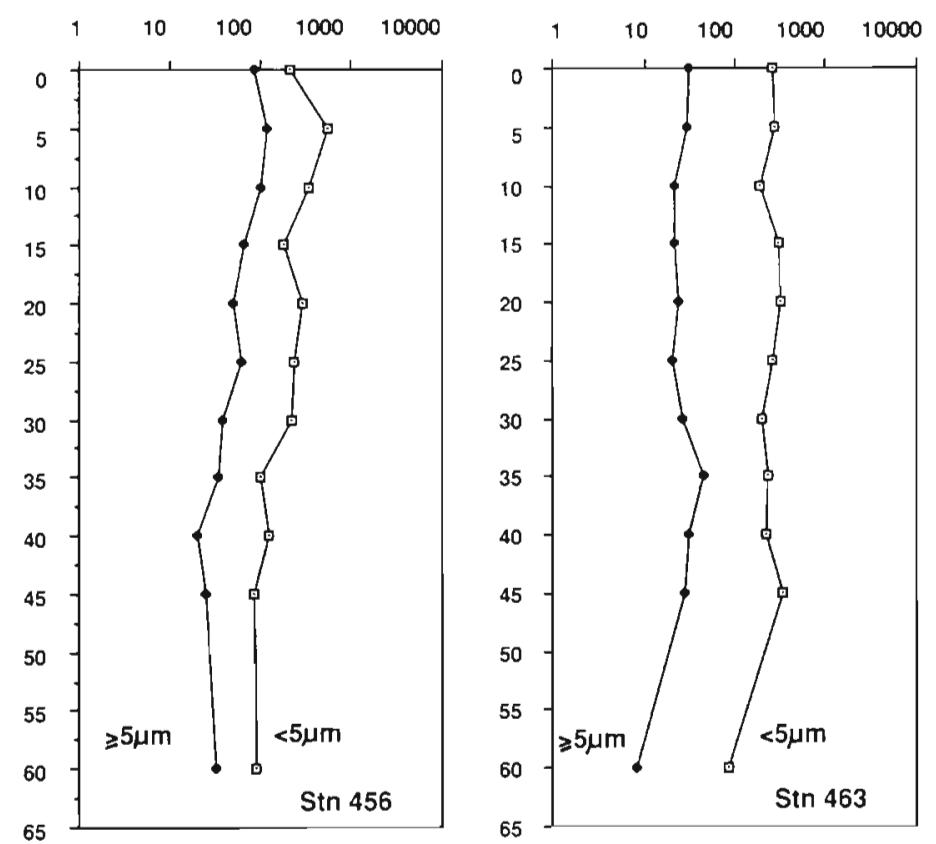

Fig. 3. Vertical profiles of phytoplankton cells and ciliates $\left(\geq 5 \mu \mathrm{m}\right.$ and $<5 \mu \mathrm{m}$ ) (cells $\mathrm{l}^{-1} \times 10^{4}$ ) for stratified (Stn 445 ), transitional ( $\operatorname{Stn} 456$ ) and mixed (Stn 463) waters

\section{RESULTS}

\section{Hydrography}

Data from UOR recordings (Poulet et al. 1988) showed the transitional thermal structure between the stratified waters of the continental shelf (Point S) and mixed waters above the continental slope (Point M) (Fig. 1). The transition between the 2 water types occurred over a narrow spatial scale (10 to $20 \mathrm{n}$ mile) corresponding to the sharp variation of the water column depth $(<200 \mathrm{~m}$ on the continental shelf, $450 \mathrm{~m}$ on the shelf-break). These hydrological structures were constant throughout the study, from 30 April to 15 May; nevertheless, at the stratified Point $\mathrm{S}$, vertical profiles of temperature and chl a pointed out a clear variability in the thermocline depth, thermal gradient values and chlorophyll biomass distribution in the water column during the experimental phase (Coombs \& Poulet 1988). Temperature and salinity profiles are compared to the present data (9 to 13 May) in Fig. 2. Vertical profiles of chlorophyll showed typical distribution in stratified water masses with a chlorophyll maximum above the thermocline (Fig. 2). However, at this time of year, the chlorophyll maximum did not exhibit a sharp peak but rather a homogenous distribution in the mixed subsurface layer where chlorophyll biomass increased with increasing stratification of the water column. Chloro- phyll values were close to $2 \mu \mathrm{g} \mathrm{l^{-1 }}$ at the relatively well-stratified station and half that in transitional and mixed waters (Fig. 2).

\section{Phytoplankton species and ciliate composition}

Stratified waters (Stn 445) showed the typical cell distribution with a maximum above the thermocline, while the transitional and mixed waters (Stns 456 and 463) exhibited a quite homogenous distribution (Fig. 3). As for chlorophyll, cell counts were higher in the stratified waters compared to the mixed waters. The ratio between small and large cells was quite constant in the mixed waters, while in the stratified waters, this ratio varied relative to the depth, and cells $>5 \mu \mathrm{m}$ declined more than cells $<5 \mu \mathrm{m}$ below the thermocline.

In the stratified waters, the vertical distribution of flagellates $<5$ and $\geq 5 \mu \mathrm{m}$ (Fig. $4 \mathrm{~A} \& \mathrm{~B}$ ) as well as diatoms (Fig. 4C) was closely related to the upper layers limited by the thermocline. In particular, Cryptophyceae were only developed above the thermocline. In contrast to the distribution of flagellates and diatoms, dinoflagellates were less related to the physical structures, and these algae were abundant below the thermocline (Fig. 4C).

At $\operatorname{Stn} 456$, in transitional waters, the vertical distribution of cells was closer to the stratified than to the mixed water column although the physical parameters 

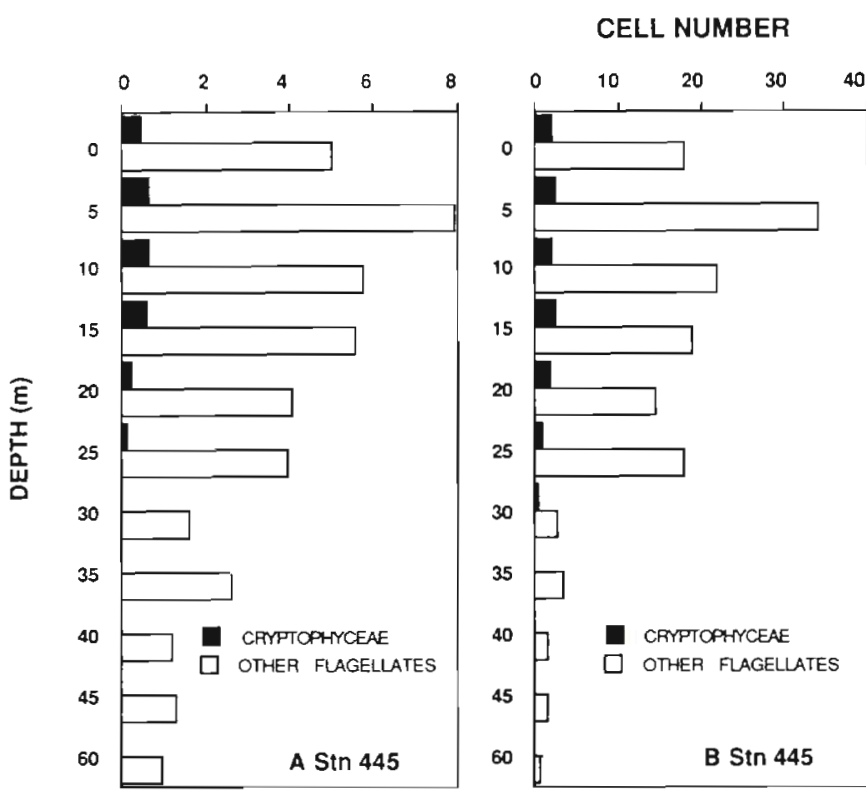

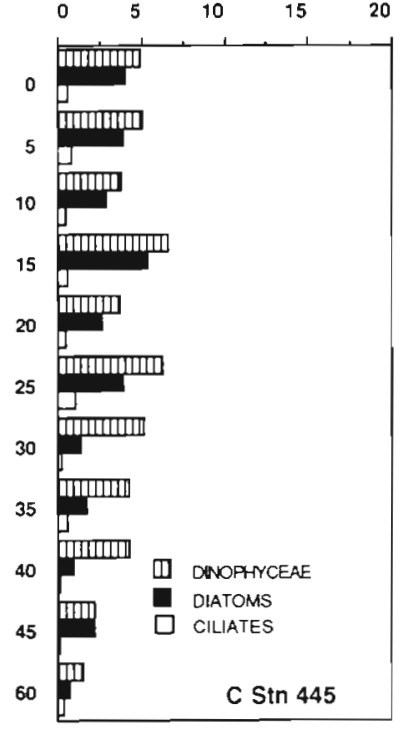

Fig. 4. Vertical distribution of the phytoplanktonic groups and ciliates in stratified waters (Str 445). (A) Cells $<5 \mu \mathrm{m} \mathrm{l}^{-1} \times 10^{6}$; (B) cells $\geq 5 \mu \mathrm{m} \mathrm{I}^{-1} \times 10^{5}$; (C) cells $\geq 5 \mu \mathrm{m} \mathrm{l}^{-1} \times 10^{4}$
(Fig. 2) allowed us to classify this station close to the mixed area. All groups and size-classes showed their maximum abundance between 0 and $10 \mathrm{~m}$ (Fig. 5A, B $\&$ C).

In mixed waters the maximal abundance of cells $\geq 5 \mu \mathrm{m}$ occurred at 5 and $35 \mathrm{~m}$ for all algae groups (Fig. $6 \mathrm{~B} \& \mathrm{C}$ ), while cells $<5 \mu \mathrm{m}$ exhibited their maximum at $20 \mathrm{~m}$ (Fig. $6 \mathrm{~A}$ ). The highest concentration of ciliates was found at $10 \mathrm{~m}\left(2.4 \times 10^{4}\right.$ cells $\left.1^{-1}\right)$ (Fig. 6C).

Abundance of each algae group varied between stratified and mixed waters (Figs. 4, 5 \& 6). For small cells $<5 \mu \mathrm{m}$, highest values of Cryptophyceae and undetermined flagellates were found in the stratified waters $\left(6.4 \times 10^{5}\right.$ and $7.9 \times 10^{6}$ cells $1^{-1}$ respectively at $5 \mathrm{~m}$ ) while the 2 other stations exhibited similar but lower abundances. Maximum abundances of dinoflagellates $\geq 5 \mu \mathrm{m}$ was found at $\operatorname{Stn} 456$ at $5 \mathrm{~m}\left(1.9 \times 10^{5}\right.$ cells $\mathrm{I}^{-1}$ ), while the typically stratified waters of Stn 445 and mixed waters of Stn 463 exhibited similar values to each other. Maximum diatom abundance also occurred at Stn 456 at $5 \mathrm{~m}\left(3.8 \times 10^{5}\right.$ cells $\left.1^{-1}\right)$, but Stn 463 (mixed waters) exhibited higher values than the stratified waters. For the Cryptophyceae and undetermined flagellates $\geq 5 \mu \mathrm{m}$, the tendency was reversed, and the maximum abundances were found in the stratified

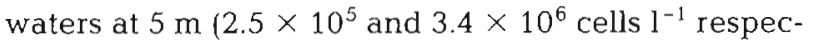

\section{CELL NUMBER}

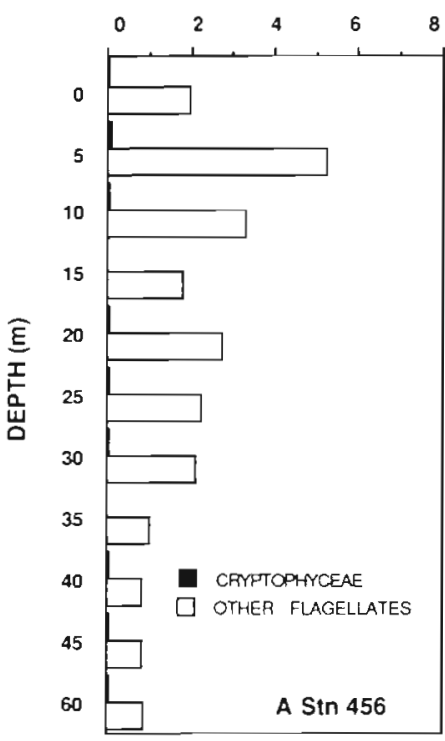

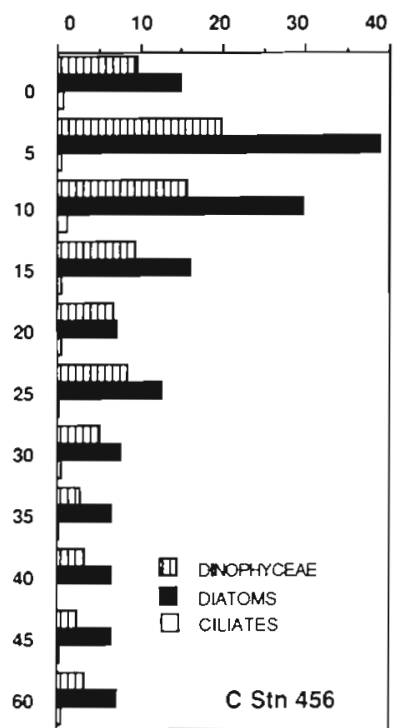

Fig. 5. Vertical distribution of the phytoplanktonic groups and ciliates in transitional waters (Stn 456). (A) Cells $<5 \mu \mathrm{m} \mathrm{l}^{-1} \times 10^{6}$; (B) cells $\geq 5 \mu \mathrm{m} \mathrm{l}^{-1} \times 10^{5}$; (C) cells $\geq 5 \mu \mathrm{m} \mathrm{l}^{-1} \times 10^{4}$ 
Fig. 6. Vertical distribution of the phytoplanktonic groups and ciliates in mixed waters (Stn 463). (A) Cells $<5 \mu \mathrm{m} \mathrm{I}^{-1}$ $\times 10^{6}$; (B) cells $\geq 5 \mu \mathrm{m} \mathrm{I}^{-1} \times$ $10^{5}$; (C) cells $\geq 5 \mu \mathrm{m} \mathrm{l}^{-1} \times 10^{4}$

tively). Stns 456 and 463 exhibited very similar abundances of Cryptophyceae, but higher values of flagellates were found at $\operatorname{Stn} 456$ than at $\operatorname{Stn} 463$.

\section{Primary production and phytoplankton growth rates}

The depth of the $1 \%$ light level ranged from $16 \mathrm{~m}$ at the most stratified station to $27 \mathrm{~m}$ in the mixed water column (Fig. 7). In the mixed subsurface layer over the entire area, primary productivity increased in the same way as chlorophyll biomass, i.e. proportionally to the degree of stratification, so that, in the well-stratified water column, daily carbon fixation was twice as high as in the mixed one (Fig. 7). By contrast, depth-integrated daily productivity exhibited a lower decrease proportional to the degree of stratification, because of a deeper light attenuation on the shelf break (Table 1).

\section{CELL NUMBER}
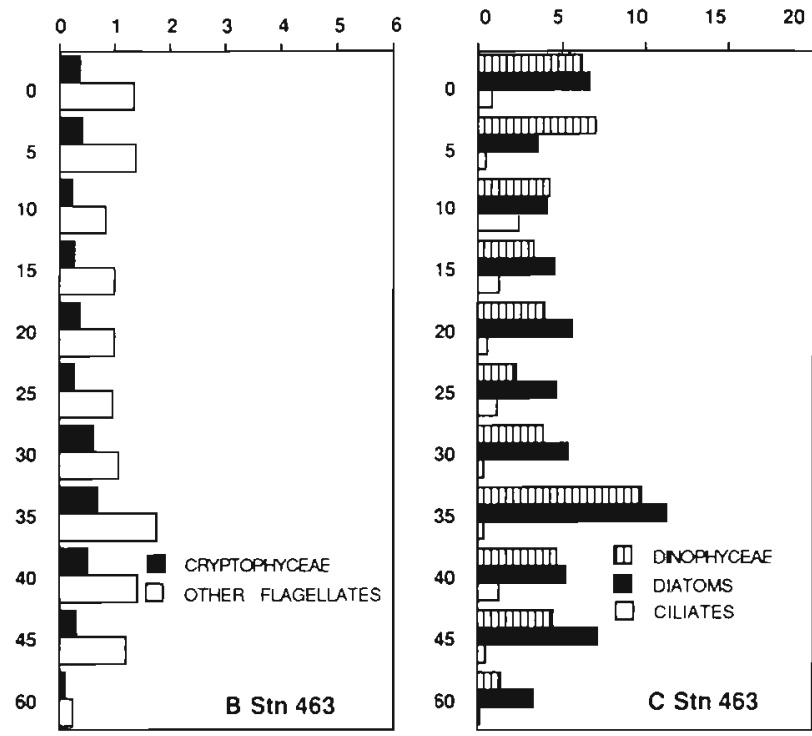

The chlorophyll distribution in size fractions of phytoplankton showed a different pattern depending upon whether the water column was well-stratified or not (Table 1). At Stn 446 (stratified waters) $96 \%$ of total depth-integrated chlorophyll was given by cells $\geq 5 \mu \mathrm{m}$, and less than $1 \%$ by cells $<1 \mu \mathrm{m}$. At the other stations, phytoplankton $<5$ and $\geq 1 \mu \mathrm{m}$ represented 7 to $10 \%$ of total integrated chlorophyll and cells $<1 \mu \mathrm{m}, 1.5$ to $1.9 \%$. Primary production of picoplankton $(<1 \mu \mathrm{m})$ was comparatively higher at all stations, varying from 6.9 to $9.1 \%$ of total carbon fixation, while production of cells $<5$ and $\geq 1 \mu \mathrm{m}$ was about $10 \%$ of the total at all stations except Stn 446 where it was not more than $6 \%$ of total carbon. These differences in chlorophyll or carbon fixation distributions are significant between the 3 size-fractions and among stations, as revealed by the ANOVA tests shown in Table 2.
Fig. 7. Downwelling irradiance (relative units: $\bullet$ ) and daily carbon fixation by total phytoplankton assemblages (mg C m${ }^{-3} \mathrm{~d}^{-1}$ : ๑) for stratified (Stn 446), transitional (Stn 458) and mixed (Stn 462) waters
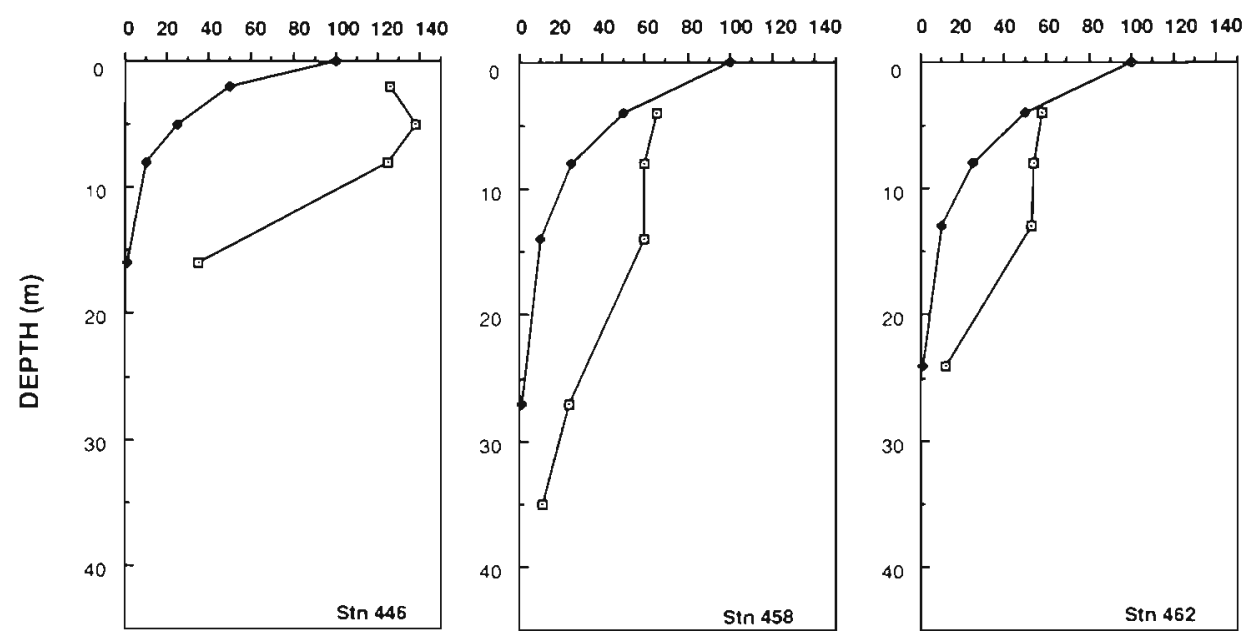
Table 1. Depth-integrated carbon fixation $(P)$ and chlorophyll biomass (chl a) for each size fraction of phytoplankton for the 3 water types. Values in parentheses are the percentage of the total fixed carbon and chlorophyll biomass

\begin{tabular}{|c|c|c|c|c|c|c|}
\hline \multirow[t]{2}{*}{ Size fractions } & \multicolumn{2}{|c|}{$\begin{array}{l}\text { Stratified } \\
(\text { Stn } 446)\end{array}$} & \multicolumn{2}{|c|}{$\begin{array}{c}\text { Transitional } \\
\text { (Stn 458) }\end{array}$} & \multicolumn{2}{|c|}{$\begin{array}{l}\text { Mixed } \\
\text { (Stn 462) }\end{array}$} \\
\hline & $\begin{array}{c}P \\
\left(m g C m^{-2} d^{-1}\right)\end{array}$ & $\begin{array}{c}\mathrm{chla} a \\
\left(\mathrm{mg} \mathrm{m}^{-2}\right)\end{array}$ & $\begin{array}{c}P \\
\left(\mathrm{mg} \mathrm{C} \mathrm{m} \mathrm{m}^{-2} \mathrm{~d}^{-1}\right)\end{array}$ & $\begin{array}{c}\mathrm{chl} \mathrm{a} \\
\left(\mathrm{mg} \mathrm{m}^{-2}\right)\end{array}$ & $\begin{array}{c}P \\
\left(\mathrm{mg} \mathrm{C} \mathrm{m} \mathrm{m}^{-2} \mathrm{~d}^{-1}\right)\end{array}$ & $\begin{array}{c}\mathrm{chl} \mathrm{a} \\
\left(\mathrm{mg} \mathrm{m}^{-2}\right)\end{array}$ \\
\hline$\geq 5 \mu \mathrm{m}$ & $\begin{array}{c}1182 \\
(86.8)\end{array}$ & $\begin{array}{l}27.30 \\
(96.4)\end{array}$ & $\begin{array}{c}902 \\
(80.9)\end{array}$ & $\begin{array}{l}19.28 \\
(87.8)\end{array}$ & $\begin{array}{c}696 \\
(81.3)\end{array}$ & $\begin{array}{c}18.6 \\
(90.7)\end{array}$ \\
\hline$<5$ to $\geq 1 \mu \mathrm{m}$ & $\begin{array}{c}85 \\
(6.3)\end{array}$ & $\begin{array}{l}0.81 \\
(2.9)\end{array}$ & $\begin{array}{l}111 \\
(10)\end{array}$ & $\begin{array}{c}2.26 \\
(10.3)\end{array}$ & $\begin{array}{c}95 \\
(11)\end{array}$ & $\begin{array}{c}1.6 \\
(7.8)\end{array}$ \\
\hline$<1 \mu \mathrm{m}$ & $\begin{array}{c}94 \\
(6.9)\end{array}$ & $\begin{array}{l}0.19 \\
(0.7)\end{array}$ & $\begin{array}{c}102 \\
(9.1)\end{array}$ & $\begin{array}{l}0.42 \\
(1.9)\end{array}$ & $\begin{array}{c}66 \\
(7.7)\end{array}$ & $\begin{array}{l}0.31 \\
(1.5)\end{array}$ \\
\hline Total & 1361 & 28.30 & 1115 & 21.96 & 856 & 20.51 \\
\hline
\end{tabular}

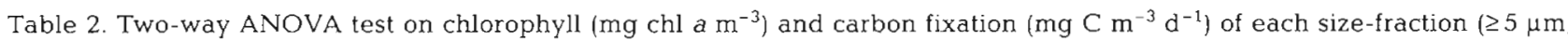
$<5$ to $\geq 1 \mu \mathrm{m},<1 \mu \mathrm{m}$ ) for each sampling depth at the 3 stations

\begin{tabular}{|c|c|c|c|c|c|}
\hline Source & Sum of squares & Degrees of freedom & Mean squares & $F$-ratio & Probability $>F$ \\
\hline \multicolumn{6}{|l|}{ Chlorophyll } \\
\hline Stations & 0.7 & 2 & 0.4 & 4.7 & 0.016 \\
\hline Size-fractions & 11.5 & 2 & 5.7 & 75.2 & 0.000 \\
\hline Interaction & 1.4 & 4 & 0.4 & 4.7 & 0.004 \\
\hline Error & 2.8 & 36 & 0.1 & & \\
\hline Total & 16.4 & 44 & & & \\
\hline \multicolumn{6}{|l|}{ Carbon fixation } \\
\hline Stations & 3529.7 & 2 & 1764.9 & 6.1 & 0.006 \\
\hline Size-fractions & 19883.2 & 2 & 9941.6 & 34.5 & 0.000 \\
\hline Interaction & 6002.8 & 4 & 1500.7 & 5.2 & 0.003 \\
\hline Error & 8643.8 & 30 & 288.1 & & \\
\hline Total & 38059.5 & 38 & & & \\
\hline
\end{tabular}

Table 3. Specific growth rate $\mu\left(\mathrm{d}^{-1}\right)$ of phytoplankton assemblages sampled at each station at the subsurface $(50 \%$ surface irradiance) and light limit (1\% surface irradiance) with SE of means in parentheses

\begin{tabular}{|cccc|}
\hline $\begin{array}{c}\text { Light sampling depth } \\
\text { (\% surface irradiance) }\end{array}$ & $\begin{array}{c}\text { Stratified } \\
(\text { Stn 446) }\end{array}$ & $\begin{array}{c}\text { Transitional } \\
(\text { Stn 458) }\end{array}$ & $\begin{array}{c}\text { Mixed } \\
(\text { Stn 462) }\end{array}$ \\
\hline 50 & $\begin{array}{c}0.690 \\
( \pm 0.06)\end{array}$ & 0.310 & $\begin{array}{c}0.100 \\
( \pm 0.004)\end{array}$ \\
& $\begin{array}{c}0.157 \\
( \pm 0.014)\end{array}$ & $\begin{array}{c}0.110 \\
( \pm 0.001)\end{array}$ & $\begin{array}{c}0.056 \\
( \pm 0.001)\end{array}$ \\
& & & \\
\hline
\end{tabular}

Specific growth rates $(\mu)$ were measured on the entire phytoplankton population (Table 3). In the upper water layers, phytoplankton growth rates were undoubtedly higher in the stratified area than in the mixed one, up to $0.69 \mathrm{~d}^{-1}$ (1 doubling per day) at Stn 446. A similar trend appeared in phytoplankton communities sampled at the light limit, but because of light limitation, $\mu$ did not exceed $0.16 \mathrm{~d}^{-1}$. Hydrological features were associated with a different structure in phytoplankton species composition and production in each cell size. As seen above, water stabilization favored larger cells ( $\geq 5 \mu \mathrm{m}$ ), of which percentage of cell number, chlorophyll content and carbon production decreased from stratified towards mixed waters both at the surface level and at the light limit.

\section{Bacterial biomass and production}

Bacterial cell number progressively increased from the stratified water column $\left(1 \times 10^{5}\right.$ cells $\left.\mathrm{ml}^{-1}\right)$ to the mixed one $\left(4 \times 10^{5}\right.$ cells $\left.\mathrm{ml}^{-1}\right)$ (Fig. 8). On the continental shelf, a conspicuous decrease in cell densities was observed just above the thermocline. At all stations, bacterial cells were more abundant below the light limit. Bacterial net production expressed as mg $\mathrm{C} \mathrm{m}^{-3} \mathrm{~d}^{-1}$ was low $(<0.2)$ in stratified waters and twice as high in mixed ones but never exceeded $0.8 \%$ of total primary production in the upper layers. At Stn 
Fig. 8. Daily carbon fixation ( $\mathrm{mg} \mathrm{C} \mathrm{m} \mathrm{m}^{-3} \mathrm{~d}^{-1}: \bullet$ ), cell numbers $\left(10^{6}\right.$ cells $\left.\mathrm{ml}^{-1}: 0\right)$ and specific growth rates, $\mu\left(\mathrm{d}^{-1}:\right.$ a) of free bacterial communities for stratified (Stn 446), transitional (Stn 458) and mixed (Stn 462) waters
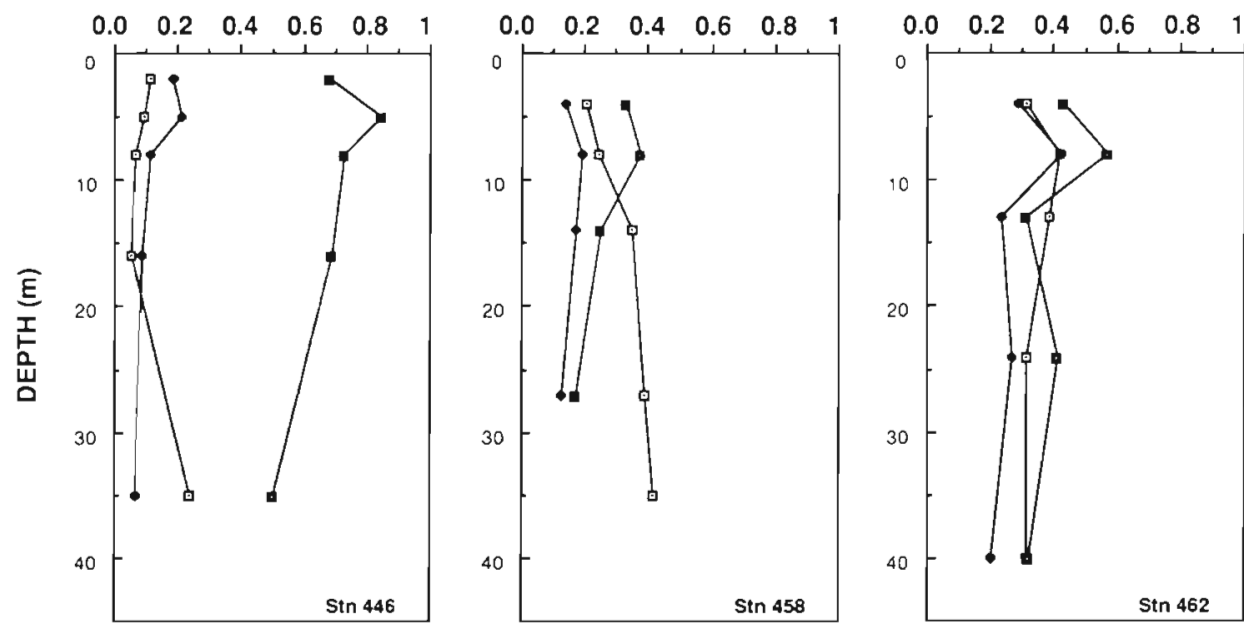

462, bacterial carbon production at the light limit reached $2 \%$ of the phytoplankton carbon production. Like the production of the $<1 \mu \mathrm{m}$ phytoplanktonic cells, bacterial carbon fixation was less than $10 \%$ in the upper layers and reached $14 \%$ at the light limit in the mixed waters (Stn 462). Bacterial growth rates showed a somewhat different picture in the 2 types of water with high values $\left(0.7 \mathrm{~d}^{-1}\right)$ in stratified waters and low values $\left(<0.4 \mathrm{~d}^{-1}\right)$ in the mixed ones.

\section{DISCUSSION}

Chlorophyll values found in the Celtic Sea in May 1987 were close to the values measured by Joint \& Pomroy (1986) in June and July 1985. In stratified waters, the vertical profile of the present study was similar to their oceanic samples (Stns P1 and P2), and the dominance of the dinoflagellates was as expected for the stratified conditions shown by these authors. But the phytoplanktonic counts in the present study were higher than the samples counted in July 1983 and October 1984 at the stratified station CS by Burkill et al. (1987). Their study station was more coastal than our stations, and this difference of biomass could be explained by the gradient of biomass between the coastal and oceanic stations in the Celtic Sea (Joint \& Pomroy 1986). The results observed in the present work were typical for the time of year. In May the spring phytoplanktonic bloom is characterized by a large fraction of diatoms (Joint et al. 1986). Chlorophyll and temperature profiles in the transitional and mixed waters were similar to the M4 profile shown by these authors in May 1984, and cell densities we observed in the transitional waters were close to the values given by these authors for April 1984 .

Phytoplankton blooms are expected to develop at stratification-destratification interfaces, due to a favor- able combination of light and nutrients. In the present study, performed on a small horizontal scale, the variable size and taxonomic distributions of phytoplankton cells complied with the expectation of dominance of large diatoms in turbulent waters and small flagellates in stratified waters (Pingree et al. $1982 \mathrm{~b}$ ). Also, the functioning of the microbial web was in accordance with the study of Holligan et al. (1984) in the western English Channel. It was shown that, in the mixed waters, growth of phytoplankton was on average low, and specific metabolic activity of the microheterotrophs was also low. By contrast, in the stratified waters, active flagellate and microheterotroph populations were found with high specific respiration rates. In the present study, specific growth rates of bacteria and phytoplankton were higher in the stratified area than in the mixed one. Due to the method we employed, the total phytoplanktonic population was measured, and we cannot preclude that a size-group was growing faster either on the continental shelf or on the shelf-break.

In accordance with the classical functioning of the primary levels of the food chain found in this area, the upper levels showed a well-known distribution. Le Fèvre \& Frontier (1988) considered the Celtic Sea shelf-break area where the 'fertilizing period' is that of the M2 tide (12 h). Based on the distribution of the biomasses, they concluded that in their case enhanced productivity was beneficial to the herbivore food chain. During our cruise, maximum copepod distribution and biomass (Williams et al. 1988) in the transitional and mixed waters corroborated this assumption. Distribution of fish larvae observed during the cruise was also related to hydrological structures (Coombs \& Camus 1988). Egg distribution was clearly linked to the physical structure of the water column in the 3 locations we studied, and greater numbers of eggs were found on tows taken in transitional and mixed 
waters than in the stratified waters (Salmon 1987). Higher numbers of larvae were found in vertically mixed waters than in stratified waters, and a more equitable depth distribution was observed. In stratified waters, larvae were concentrated within and above the thermocline (Salmon 1987).

However, variation in the structure of the pelagic food web, which is thought to occur on seasonal and oceanwide scales (Cushing 1989), may recur on much finer temporal and horizontal scales (cf. Kiørboe et al. 1990). The state of the 3 different water types studied during this cruise was related to the horizontal variations of the physico-chemical parameters, as well as to the development of the organisms during this time of the year.

Differences occurred in the present study between the 2 areas (transitional and mixed) in which unstratified conditions prevailed (Fig. 2). The specific composition of the phytoplankton was quite similar at Stns 463 and 456 , dominated by diatoms in the $\geq 5 \mu \mathrm{m}$ size class (Figs. $5 \& 6$ ). In contrast, dinoflagellates and other flagellates prevailed in the stratified waters (Stn 445) (Fig. 4). However, the vertical distribution at Stn 456 was closer to the stratified profiles, with a subsurface maximum of cells, compared to the constant vertical distribution of organisms at the mixed station (Stn 463) (Figs. 2 \& 3). Biological survey of fronts on the northwest European continental shelf was well-documented by Holligan (1981) but little information was given on the phytoplankton distribution at the Celtic shelf-break. Holligan (1981) focused on the abrupt changes at the edge of the continental shelf and the patchiness of chlorophyll, although the general distribution of the species agreed with the general pattern of stratified, frontal and mixed waters. This could explain part of the differences between Stns 463 and 456. The phytoplankton distribution in our study must have adapted to the topographic situation which induced a rapid change of the physico-chemical conditions on a small horizontal scale. Also, the spring tide regime which prevailed during this study certainly affected the hydrodynamical characteristics of the water masses, and could explain the water column structures we observed in this region.

The consequences of contrasting hydrographic regimes, in terms of both the relative biomass and the rates of turnover of primary producers, were docu-

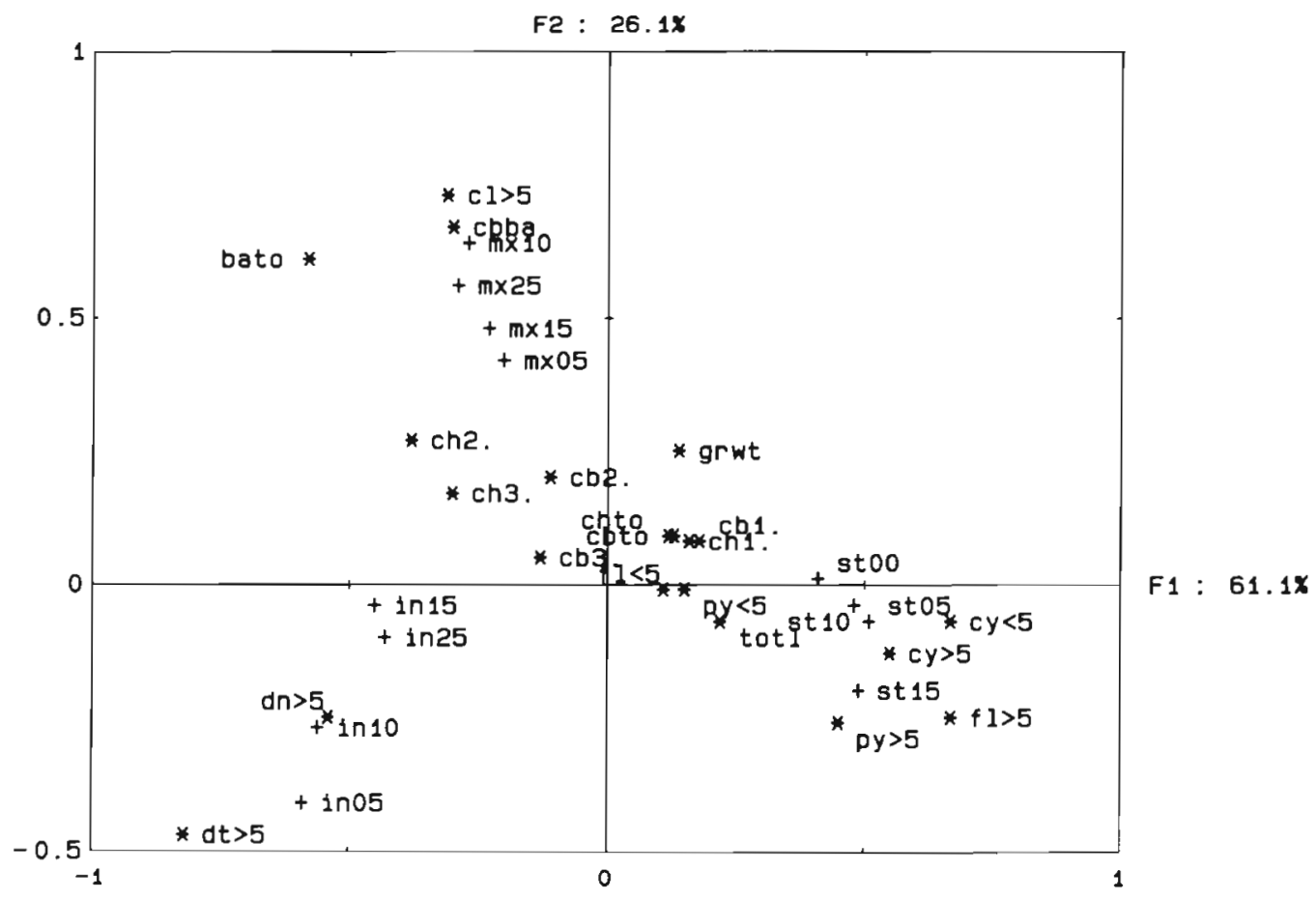

Fig. 9. Correspondence analysis relative to the composition and the carbon production of bacteria and phytoplankton at the 3 studied stations and for data from the upper $25 \mathrm{~m}$ layers. bato: Bacterial biomass, cells $\mathrm{ml}^{-1} ; \mathrm{cb}_{1}$ : carbon production, $\mathrm{mg} \mathrm{m}^{-3} \mathrm{~d}^{-1}$, for cells $200-5 \mu \mathrm{m}$; cb2.: carbon production, $\mathrm{mg} \mathrm{m}^{-3} \mathrm{~d}^{-1}$, for cells $5-1 \mu \mathrm{m}$; cb3.: carbon production, $\mathrm{mg} \mathrm{m}^{-3} \mathrm{~d}^{-1}$, for cells $<1 \mu \mathrm{m}$; cbto: total carbon production, $\mathrm{mg} \mathrm{m}^{-3} \mathrm{~d}^{-1}$; ccba: bacterial carbon, $\mathrm{mg} \mathrm{m}^{-3} \mathrm{~d}^{-1}$; ch1.: chl cell ${ }^{-1}$ for size $200-5 \mu \mathrm{m}$; ch2.: chl cell ${ }^{-1}$ for size 5-1 $\mu \mathrm{m}_{i}$ ch $3 .:$ chl cell ${ }^{-1}$ for size $<1 \mu \mathrm{m}_{\text {; }}$ chto: total chlorophyll, $\mathrm{mg} \mathrm{m}^{-3}$; cl: ciliates; cy: Cryptophyceae; dn: Dinophyceae; dt: diatoms; fl: flagellates; grwt: bacterial growth, $\mu \mathrm{d}^{-1}$; in: transitional waters; $\mathrm{mx}$ : mixed waters; py<5: total cells $<5 \mu \mathrm{m} \mathrm{l}^{-1}$; py $>5$ : total cells $>5 \mu \mathrm{m} \mathrm{l}^{-1}$; st: stratified waters; totl: total cells $\mathrm{I}^{-1}$; $<5$ : cells $<5 \mu \mathrm{m}$; $>5$ : cells $>5 \mu \mathrm{m}$; $00: 0 \mathrm{~m}$; $05: 5 \mathrm{~m}$; 10: $10 \mathrm{~m} ; 15: 15 \mathrm{~m} ; 25: 25 \mathrm{~m}$. (*) Data on composition and carbon production of bacteria and phytoplankton; (+) locality (station and depth) where data was obtained 
mented by the correspondence analysis shown in Fig. 9. This diagram characterizes the upper $25 \mathrm{~m}$ layers, corresponding to the euphotic zone in the mixed waters, and the layers above the thermocline in the stratified waters. This analysis shows differences in the composition and production of phytoplankton as well as in bacteria at the different stations. On the first axis ( $F 1)$ the major contributions (>0.50\%) were made by diatoms, dinoflagellates and bacterial biomass of the transitional and mixed waters, in contrast to the Cryptophyceae and flagellates $\geq 5 \mu \mathrm{m}$ of the stratified waters. On the second axis (F2), the major contributions ( $>0.50 \%$ ) were made by diatoms of the transitional waters, as opposed to bacterial biomass, production and growth, and ciliates of the mixed waters. So, in this analysis, the major distinction (F1 = $61 \%$ of the variability) was related to the stratified waters in contrast to the transitional and mixed ones, and the second distinction (F2 $=26 \%$ of the variability) was related to the contrast between the mixed and the transitional waters. Therefore, each station was characterized by its own parameters: mixed waters (Stn 463) = bacterial biomass, bacterial carbon production and ciliate biomass; transitional waters (Stn 456) = diatom and dinoflagellate biomass; stratified waters (Stn 445) = Cryptophyceae, flagellate and total phytoplankton biomass.

In Fig. 9, chlorophyll (chto, ch1, ch2, ch3) as well as phytoplankton carbon production (cbto, cb1, cb2, cb3) appeared independent of the 3 locations. This demonstrates, as already made clear by Kiørboe (1989), that chlorophyll alone is not sufficient to study this particularly variable and complex environment. Also, the bacterial specific growth rate (grwt) appeared independent of the stations. In comparison, the bacterial biomass (bato) and the carbon production (ccba) were clearly related to the mixed waters (Fig. 6). This suggests that interpretable relations to relevant environmental variables, as noted by Kiørboe et al. (1990), could be different for phytoplankton and bacteria.

Also, waters described as 'mixed' showed a greater activity of the microbial loop than the stratified ones. In particular, unusually high ciliate biomass was found in the mixed waters at Stn 463 (cf. Carlough \& Meyer 1989, Nielsen \& Kiørboe 1991) although phytoplankton distribution and composition were as in the previous description, and linked this station to the classical 'mixed' terminology.

In this study, we observed an unusual distribution of organisms and an unusual functioning of these different trophic levels compared to previous knowledge of stratified and mixed waters (Joint \& Williams 1985). Bacteria and ciliates were abundant in the mixed waters (Fig. 9), and thus were not 'classical' relative to the structure of the food web. Contradictory results on larval feeding and survival were also seen during this cruise. In mixed waters, spawning was more intense, and a higher frequency of mackerel larvae with food in their guts was found while their mortality was higher (Salmon 1987). Some specific observations perhaps could explain these discrepancies and argue for an earlier establishment of the successional bloom of the phytoplankton than the previous studies performed at this time of year. The first observation is that the morphometric measures of larvae were higher for May 1987 than for previous years (Salmon 1987), which means that older larvae were sampled during this cruise rather than during the previous cruises. The second is related to the schedule of the successional pattern that occurs after the establishment of the thermocline (Pingree et al. 1978): first a mixture of dinoflagellates and diatoms, then dinoflagellates and finally flagellates. These authors focused on the hypothesis that dinoflagellates become dominant when the major source of usable phosphorus and nitrogen is regenerated from the degradation of dissolved organic compounds by bacteria. This could explain the different phytoplankton composition of the transitional and mixed waters, especially for Stn 456, which was the richest in dinoflagellates, if the study coincided with the end of the phytoplankton bloom. Additionally, the richer bacterial and ciliate biomass in the mixed waters could be linked to the presence of larvae, which cause some degradative processes. Probably, the tidal regime which prevailed during the sampling period enhanced the different structures of the water masses, and in association with the establishment of the food chain towards the fish larvae, could explain the different pictures we observed in this area at this time of the year.

Acknowledgements. This work was supported in part by the Centre National de la Recherche Scientifique (CNRS), the Natural Environment Research Council (NERC), the Ministry of Agriculture, Fisheries and Food (MAFF) and the European Economic Community (ECC: Action de stimulation, contrat $\mathrm{n}^{\circ}$ ST2J-0369). Thanks are due to the Plymouth Marine Laboratory (PML) for providing the physical data. We thank D. Conway, R. Williams, S. Coombs and P. Salmon for providing the information on the zooplankton and the fish larvae. We greatly thank Eileen O'Ceidigh for the correction of the English manuscript, and Claude Le Roux for the statistical analysis.

\section{LITERATURE CITED}

Benzecri, J. P. (1970). La pratique de l'analyse des correspondances. Cahier $n^{\circ} 2$ du laboratoire des Statistiques Mathématiques, Faculté des Sciences, Paris

Bjørnsen, P. K., Riemann, B., Horsted, S. J., Nielsen, T. G., Pock-Sten, J. (1988). Trophic interactions between heterotrophic nanoflagellates and bacterioplankton in manipulated seawater enclosures. Limnol. Oceanogr. 33: 409-420 
Burkill, P. H., Mantoura, R. F. C., Llewellyn, C. A., Owens, N. J. P. (1987). Microzooplankton grazing and selectivity of phytoplankton in coastal waters. Mar. Biol. 93: $581-590$

Carlough, L. A., Meyer, J. L. (1989). Protozoans in two southeastern blackwater rivers and their importance to trophic transfer. Limnol. Oceanogr. 34: 163-177

Coombs, S. H., Camus, P. (1988). Ichtyoplankton. In: Structures environmentales et conditions trophiques en relation avec la survie et le recrutement des larves de poissons pélagiques. Rapp. $\mathrm{n}^{\circ} 1$, Contrat $\mathrm{n}^{\circ}$ ST2J-0369 (EDB). Commission des Communautés Européennes, Bruxelles, p. 23-24

Coombs, S. H., Lindley, J. A., Fosh, C. A. (1983). Vertical distribution of larvae of mackerel Scomber scombrus and microplankton, with some conclusions on feeding conditions and survey methods. Proceedings of the expert consultation to examine changes in abundance and species composition of neritic fish resources. San José, Costa Rica, 18-29 April 1983. F.A.O. Fish. Report no. 291. 3: $939-956$

Coombs, S. H., Poulet, S. A. (1988). Caractéristiques hydrographiques du milieu. In: Structures environmentales et conditions trophiques en relation avec la survie et le recrutement des larves de poissons pélagiques. Rapp. $n^{0} 1$, Contrat $n^{\circ}$ ST2J-0369 (EDB). Commission des Communautés Européennes, Bruxelles, p. 6-8

Cushing, D. H. (1975). Marine ecology and fisheries Cambridge University Press, Cambridge

Cushing, D. H. (1989). A difference in structure between ecosystems in strongly stratified waters and in those that are only weakly stratified. J. Plankton Res. 11: 1-13

Fuhrman, J. A., Ammerman, J. W., Azam, F. (1980). Bacterioplankton in the coastal euphotic zone: distribution, activity and possible relationship with phytoplankton. Mar. Biol. 60: $201-207$

Fuhrhman, J. A., Azam, F. (1982). Thymidine incorporation as a measure of heterotrophic bacterioplankton production in marine surface waters: evaluation and field results. Mar. Biol. 66: 109-120

Holligan, P. M. (1981). Biological implications of fronts on the northwest European continental shelf. Phil. Trans. R. Soc. Ser. A 302: 547-562

Holligan, P. M., Williams, P. J. LeB., Purdie, D., Harris, R. P. (1984). Photosynthesis, respiration and nitrogen supply of plankton populations in stratified, frontal and tidally mixed shelf waters. Mar. Ecol. Prog. Ser. 17: 201-213

Iles, T. D. Sinclair, M. (1982). Atlantic herring: stock discreteness and abundance. Science 215: 627-633

Iles, T. D., Sinclair, M. (1985). An instance of herring larval retention in the North Sea. Count. Meet. int. Comm. Explor. Sea C.M. ICES/H: 43

Jeffrey, S. W. (1981), An irnproved thin-layer chromatographic technique for marine phytoplankton pigments. Limnol. Oceanogr. 26: 191-197

Joint, I. R., Owens, N. J. P., Pomroy, A. J. (1986). Seasonal production of photosynthetic picoplankton and namoplankton in the Celtic Sea. Mar. Ecol. Prog. Ser. 28: 251-258

Joint, I. R., Pomroy, A. J. (1986). Photosynthetic characteristics of nanoplankton and picoplankton from the surface mixed layer. Mar. Biol. 92: 465-474

Joint, I. R., Williams, R. (1985). Demands of the herbivore community on phytoplankton production in the Celtic Sea in August. Mar. Biol. 87: 297-306

Kiørboe, T. (1989). Phytoplankton growth rate and nitrogen content: implications for feeding and fecundity in a herbivorous copepod. Mar. Ecol. Prog. Ser. 55: 229-234
Kiørboe, T., Kaas, H., Kruse, P., Mohlenberg, F., Tiselius, P., Extebjerg, G. (1990). The structure of the pelagic food web in relation to water column structure in the Skagerrak. Mar. Ecol. Prog. Ser. 59: 19-32

Kiorboe, T., Munk, P., Richarson, K., Christensen, V., Paulsen, H. (1988). Plankton dynamics and larval herring growth, drift and survival in a frontal area. Mar. Ecol. Prog. Ser. 44: 205-219

Kuosa, H., Kivi, K. (1989). Bacteria and heterotrophic flagellates in the pelagic carbon cycle in the Northern Baltic Sea. Mar. Ecol. Prog. Ser. 53: 93-100

Lasker, R. (1975). Field criteria for survival of anchovy larvae. The relation between inshore chlorophyll maximum layers and successful first feeding. Fish. Bull. U.S. 73: $453-462$

Lasker, R. (1981). Factors contributing to variable recruitment of the northern anchovy (Engraulix mordax) in the California current: contrasting years 1975 through 1978 Rapp. P.-v. Réun. Cons. int. Explor. Mer 178: 375-388

Le Fèvre, J., Frontier, S. (1988). Influence of temporal characteristics of physical phenomena on plankton dynamics, as shown by north-west European marine ecosystems In: Rothschild, B. J. (ed.). Toward a theory on biologicalphysical interactions in the world ocean. Kluwer Academic Publishers, Dordrecht, p. 245-272

Legendre, L., Le Fèvre, L. (1989). Hydrodynamical singularities as control of recycled versus export production in oceans. In: Berger, W. H., Smetacek, V. S., Wefer, G. (eds.) Productivity of the ocean: present and past. J. Wiley \& Sons, Dahlem, p. 49-63

Lorenzen, C. J. (1966). A method for the continuous measurement of in vivo chlorophyll concentration. Deep Sea Res. 13: $223-227$

Nielsen, T. G., Kiørboe, T. (1991). Effects of a storm event on the structure of the pelagic food web with special emphasis on planktonic ciliates. J. Plankton Res. 13:35-51

Pingree, R. D., Holligan, P. M., Mardell, G. T. (1978). The effects of vertical stability on phytoplankton distributions in the summer on the northwest European Shelf. Deep Sea Res. 25: 1011-1028

Pingree, R. D., Holligan, P. M., Mardell, G. T., Harris, R. P. (1982a). Vertical distribution of plankton in the Skagerrak in relation to doming of seasonal thermocline. Cont. Shelf Res. 1: 209-219

Pingree, R. D., Mardell, G. T (1981). Slope turbulence, internal waves and phytoplankton growth at the Celtic Sea shelf-break. Phil. Trans. R. Soc. Ser. A 302: 663-682

Pingree, R. D., Mardell, G. T., Holligan, P. M., Griffiths D. K., Smithers, J. (1982b). Celtic Sea and Armorican current structure and the vertical distributions of temperature and chlorophyll. Cont. Shelf Res. 1: 99-116

Poulet, S. A., Ben Mlih, F., Camus, P., Conway, D. V. P., Coombs, S. H., Martin-Jézéquel, V., Marty, J.-C., Videau, C., Williams, R. (1988). Structures environmentales et conditions trophiques en relation avec la survie et le recrutement des larves de poissons pélagiques. Rapp. $\mathrm{n}^{\circ} 1$, Contrat n ${ }^{\circ}$ ST2J-0369 (EDB) Commission des Communautés Européennes, Bruxelles

Redalje, D. J., Laws, E. A. (1981). A new method for estimating phytoplankton growth rates and carbon biomass. Mar. Biol. 62: 73-79

Salmon, P. L. (1987). Feeding conditions for mackerel larvae (Scomber scombrus L.) at a stratified and mixed station at the Celtic Sea shelf edge. M.Sc. thesis, Plymouth Polytechnic

Sherr, E. B., Sherr, B. F. (1987). High rates of consumption of bacteria by pelagic ciliates. Nature, Lond. 325: $710-711$ 
Teil, M. (1975). Correspondence factor analysis: an outline of its method. Math. Geol. 7: 3-12

Watson, S. W., Novitsky, T. J., Quinby, I. C., Valois, F. W. (1977). Determination of bacterial number and biomass in the marine environment. Appl. environ. Microbiol. 33: 940-946

Welschmeyer, N. A., Lorenzen, C. J. (1984). Carbon-14 labeling of phytoplankton and chlorophyll a carbon: determination of specific growth rates. Limnol. Oceanogr. 29: 135-145

This article was submitted to the editor
Williams, R., Conway, D., Coombs, S. (1988). Zooplankton. In: Structures environmentales et conditions trophiques en relation avec la survie et le recrutement des larves de poissons pélagiques. Rapp. $\mathrm{n}^{\circ} 1$, Contrat $\mathrm{n}^{\circ} \mathrm{ST} 2 \mathrm{~J}-0369$ (EDB) Commission des Communautés Européennes, Bruxelles, p. 20-22

Yentsch, C. S., Menzel, D. W. (1963). A method for the determination of phytoplankton chlorophyll and pheophytin by fluorescence. Deep Sea Res. 10: 221-231

Manuscript first received: January 23, 1992

Revised version accepted: June 15, 1992 